\title{
Pemanfaatan Cyber Extension melalui Telepon Genggam oleh Petani Anggrek di Taman Anggrek Ragunan, Jakarta Selatan
}

\section{Utilization of Cyber Extension via Mobile Phones by Farmers in Ragunan Orchid Park, South Jakarta}

\author{
Aira Putri Eri Dasli ${ }^{1}$, Pudji Muljono ${ }^{2}$, Djoko Susanto ${ }^{2}$ \\ ${ }^{1}$ Program Studi Ilmu Penyuluhan Pembangunan, Sekolah Pascasarjana, \\ Institut Pertanian Bogor, Bogor \\ ${ }^{2}$ Departemen Sains Komunikasi dan Pengembangan Masyarakat, \\ Fakultas Ekologi Manusia, Institut Pertanian Bogor, Bogor
}

\begin{abstract}
Cyber extension is one of the modern technology which can be utilized by the farmers, extension workers, and Business actors to obtain informations and develop agricultural business. The purpose of this study was to analyze relationship between characteristics of respondents and environmental with the farmers behavior in utilizing cyber extension (Hp and internet) to support farming activities as well as the utilized on farm orchid plants. This study is descriptive correlational type of survey method. Research conducted at the Ragunan Orchid Park, South Jakarta, Jakarta Province. The sample were all growers of orchids as many as 35 people. The behavior of farmers for using cyber media, especially utilized of mobile phones. It also had a positive utilized in the development of farming, especially in marketing orchids in town and out of town. So, the farmers increase consumer and profit.
\end{abstract}

Keywords: cyber extension, extension workers, utilized, handphone

\begin{abstract}
Abstrak
Cyber extension merupakan salah satu media penyuluhan berbasis teknologi modern yang dapat dimanfaatkan oleh petani, penyuluh dan pelaku usaha untuk memperoleh informasi dan mengembangkan usaha pertanian. Tujuan penelitian ini adalah menganalisis hubungan karakteristik responden dan lingkungan dengan perilaku petani dalam pemanfaatan cyber extension (Hp dan internet) untuk mendukung kegiatan usaha tani serta manfaat terhadap usaha tani tanaman anggrek menggunakan cyber extension. Penelitian ini merupakan penelitian deskriptif korelasional dengan menggunakan metode survei. Penelitian dilaksanakan di Taman Anggrek Ragunan, Jakarta Selatan, Provinsi DKI Jakarta. Sampel dalam penelitian ini adalah seluruh petani tanaman anggrek sebanyak 35 orang. Perilaku petani dalam menggunakan media cyber extension terkhusus pada pemanfaatan telepon genggam. Hal ini juga memberikan manfaat yang positif dalam pengembangan usaha tani terutama dalam memasarkan tanaman anggrek ke dalam maupun luar kota, sehingga petani mengalami peningkatan konsumen dan keuntungan.
\end{abstract}

Kata kunci: cyber extension, penyuluh, manfaat, telepon genggam

\section{Pendahuluan}

Indonesia dan negara Asean menghadapi pasar bebas Asean atau Asean Free Trade Area (AFTA) pada tahun 2015, di mana seluruh negara yang bergabung dalam Asean dapat melakukan transaksi perdagangan secara bebas. Dengan adanya kondisi tersebut, Indonesia merupakan salah satu pasar yang menjadi incaran para pengusaha negara Asean untuk mengembangkan usaha. Hal ini menjadi peluang bagi pengusaha dari Indonesia maupun petani untuk dapat mengembangkan usaha dan bersaing.
Untuk dapat bersaing dengan negara Asean lainnya, dibutuhkan pengetahuan dan keterampilan yang lebih baik sebagai senjata dalam bersaing.

Pemanfaatan teknologi dan sumber daya alam yang dimiliki oleh Indonesia merupakan salah satu keunggulan yang dapat dikembangkan menjadi senjata dalam bersaing. Keragaman hayati yang dimiliki Indonesia menjadi nilai jual yang sangat tinggi, seperti pada komoditi tanaman hias khususnya tanaman anggrek. Tanaman anggrek memiliki komunitas pencinta yang sangat tinggi. Indonesia memiliki jenis - jenis tanaman anggrek yang sangat langka dan

\footnotetext{
${ }^{1}$ Korespondensi penulis

E-mail: airaputrieridasli@gmail.com
} 
unik sehingga dapat bersaing didunia Internasional. Salah satu cara untuk dapat bersaing dengan pasar dunia adalah dengan belajar memanfaatkan teknologi informasi sebagai media.

Susanto (2008), tidak ada cara yang lebih tepat untuk meningkatkan kualitas SDM selain melalui belajar. Petani, penyuluh dan stakeholders dapat belajar untuk menggunakan teknologi. Dengan menggunakan teknologi, penyuluh, petani, maupun pengusaha tanaman anggrek dapat melihat bagaimana perkembangan tanaman anggrek yang sedang di minati, pembudidayaan dan pemanenan bahkan dapat melakukan transaksi jual beli. Alemna dan Sam (2006) menyatakan bahwa dengan adanya pertukaran informasi melalui pemanfaatan peralatan elektronis telah merevitalisasi peranan dari layanan penyuluhan dalam penyiapan informasi, pendidikan, dan membantu dalam proses pengambilan keputusan untuk produsen pertanian di India.

Cyber extension merupakan salah satu mekanisme pengembangan jaringan komunikasi informasi inovasi pertanian yang terprogram secara efektif dengan mengimplementasikan teknologi, informasi dan komunikasi dalam sistem komunikasi inovasi atau penyuluhan pertanian. Cyber extension diharapkan dapat meningkatkan keberdayaan petani melalui penyiapan informasi pertanian yang tepat waktu dan relevan kepada petani dalam mendukung proses pengambilan keputusan berusaha tani untuk meningkatkan produktivitasnya. Cyber extension juga merupakan salah satu mekanisme komunikasi inovasi pertanian yang dapat difungsikan untuk mempertemukan lembaga penelitian, pengembangan, dan pengkajian dengan diseminator inovasi (penyuluh), pendidik, petani, dan kelompok stakeholders lainnya yang masing-masing memiliki kebutuhan dengan jenis dan bentuk informasi yang berbeda sehingga dapat berperan secara sinergis dan saling melengkapi (Sumardjo et al., 2009).

Keuntungan yang potensial dari komunikasi cyber extension adalah ketersediaan yang secara terus menerus, kekayaan informasi (informasi nyaris tanpa batas), jangkauan wilayah internasional secara instan, pendekatan yang berorientasi kepada penerima, bersifat pribadi (individual), dan menghemat biaya, waktu, dan tenaga (Adekoya, 2007). Cyber extensionmerupakan salah satu saluran komunikasi yang mensinergikan aplikasi teknologi informasi dengan beragam sistem komunikasi.
Cyber extension juga merupakan tipe khusus dari suatu inovasi. Istilah saluran merupakan sebuah terminologi yang penting untuk pembelajaran inovasi karena memiliki beragam aplikasi yang sangat luas, namun memiliki makna yang sangat spesifik (Browning et al., 2008).

Taragola dan Gelb (2009), berdasarkan survei yang dilakukan oleh the International Society for Horticultural Sciences (ISHS) hambatanhambatan dalam mengadopsi teknologi informasi dan komunikasi (TIK) oleh petani khususnya petani hortikultura, yaitu: keterbatasan kemampuan, kesenjangan dalam pelatihan (training), kesadaran akan manfaat TIK, waktu, biaya dari teknologi yang digunakan, integrasi sistem dan ketersediaan software. Untuk responden dari negara-negara berkembang, lebih menekankan pentingnya "biaya teknologi TIK" dan "kesenjangan infrastruktur teknologi.

Cyber extension merupakan salah satu bentuk media komunikasi yang digunakan untuk dapat memperoleh informasi yang dapat di akses tanpa terikat waktu. Salah satu contoh pemanfaatan cyber extensionadalah melalui pemanfaatan telepon genggam. Dalam penelitian ini, pemanfaatan cyber extension di fokuskan untuk melihat manfaat dari telepon genggam dalam mengakses informasi dan manfaat terhadap usaha tani. Penggunaan telepon genggam bagi petani di Taman Anggrek Ragunan sudah menjadi barang kebutuhan utama dalam keseharian. Telepon genggam digunakan untuk berkomunikasi dengan konsumen dan mencari informasi yang dibutuhkan.

Provinsi DKIJakarta sebagaipusat pemerintahan dan pusat informasi, memiliki pasar tanaman hias khususnya tanaman anggrek, yang menjadi daya tarik wisatawan. Pemerintah DKI memiliki taman anggrek Ragunan yang terletak di Jakarta Selatan. Taman anggrek Ragunan merupakan sentral tanaman hias khususnya anggrek yang berfungsi sebagai agrowisata dan sekaligus sebagai pasar tanaman hias terutama anggrek yang melayani pembelian baik eceran maupun grosir. Taman anggrek Ragunan merupakan aset Pemerintah DKI Jakarta yang dikelola oleh Gabungan Kelompok Tani (Prima Tani) dengan luas \pm 45 Ha dan terbagi dalam 45 kavling, sehingga masing-masing kavling seluas 1 Ha yang berupa Screen House yang dikelola oleh 1 orang petani dan dibantu oleh 3 orang karyawan. 


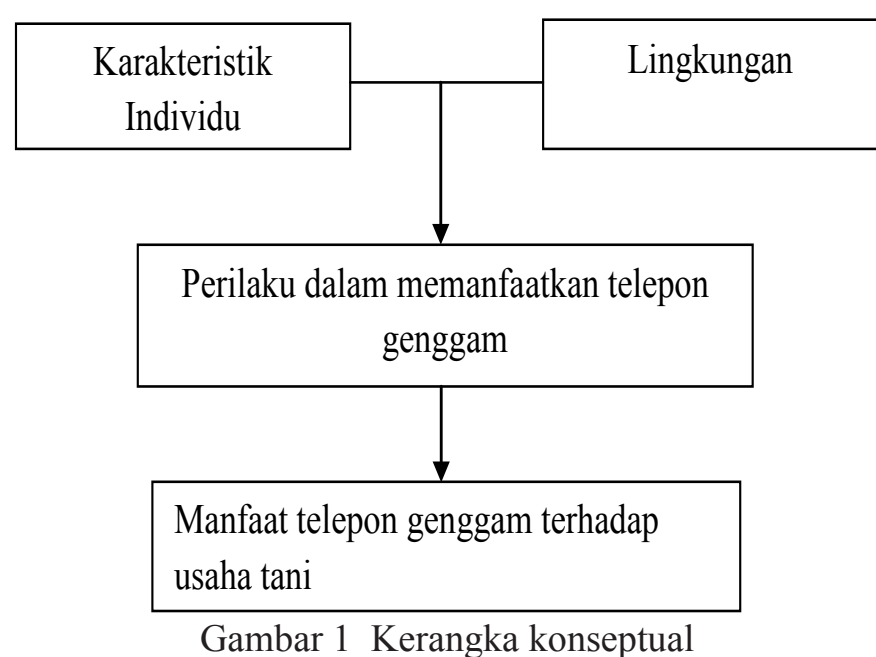

Namun, terdapat beberapa kavling yang dimiliki oleh satu orang, sehingga jumlah penyewa kavling sebanyak 35 orang. Petani anggrek menyewa lahan kepada Pemerintah DKI Jakarta dan MOU dengan jangka waktu 5 tahun dapat diperpanjang dengan pembayaran setiap bulan. Dalam mengembangkan usaha tani, akses informasi dan pemanfaatan teknologi, serta pemanfaatan cyber extensionmelalui telepon genggam membantu dalam memasarkan tanaman anggrek dan mengetahui komoditas yang sedang berkembang. Komoditi tanaman anggrek yang dikembangkan di taman ini terdiri dari beberapa jenis, namun yang menjadi unggulan adalah jenis anggrek dendrobium dan anggrek bulan.

Analisis pemanfaatan cyber extensionmelalui telepon genggam merupakan salah satu upaya dalam meningkatkan peran teknologi informasi dan komunikasi dalam mengembangkan sistem informasi pertanian. Sebagai media penyuluhan, cyberextension diharapkan dapat membantu petani, penyuluh maupun pelaku usaha untuk dapat mengembangkan usaha. Maka tujuan dari penelitian ini adalah menganalisis hubungan karakteristik responden dan lingkungan dengan perilaku responden serta manfaat terhadap usaha tani tanaman anggrek. Gambaran kerangka konseptual dari penelitian, tersaji dalam Gambar 1.

\section{Metode Penelitian}

Berdasarkan tujuan penelitian, penelitian ini bersifat deskriptif korelasional. Penelitian ini mendeskripsikan peubah yang berupaya menjelaskan hubungan antara peubah bebas yaitu karakteristik responden dan lingkungan dalam memanfaatkan cyber extension. Peubah tidak bebasnya adalah perilaku dalam pemanfaatan cyber extension dan manfaat usaha tani tanaman anggrek.

Metode penelitian menggunakan metode survei dengan pendekatan kuantitatif. Penelitian ini dilaksanakan di lokasi Taman Anggrek Ragunan Jakarta Selatan. Pengumpulan data dilakukan pada bulan Februari - Maret 2015. Teknik pengumpulan data dilakukan dengan menggunakan kuesioner, interview, dan juga dokumentasi. Populasi dalam penelitian ini adalah seluruh petani tanaman anggrek yang berada di Taman Anggrek Ragunan, Jakarta Selatan. Penelitian ini menggunakan metode sensus, merupakan suatu teknik pengambilan sampel yang meliputi keseluruhan jumlah anggota populasi (Arikunto, 1998). Hal ini dikarenakan jumlah populasi yang tidak terlalu banyak sehingga jumlah responden sebanyak 35 orang. Analisis data yang digunakan adalah analisis koefisien korelasi pearson product moment (r) untuk mengetahui hubungan peubah independen dengan peubah dependen dengan rumus sebagai berikut.

$$
\mathrm{xy}=\frac{\mathrm{N} \sum \mathrm{XY}-\left(\sum \mathrm{X}\right)\left(\sum \mathrm{Y}\right)}{\sqrt{\left[\mathrm{N} \sum \mathrm{X}^{2}-\left(\sum \mathrm{X}\right)^{2}\right]\left[\sum \mathrm{Y}^{2}-\left(\sum \mathrm{Y}\right)^{2}\right]}}
$$

(Johnson dan Witchern, 2002)

\section{Keterangan :}

$\mathrm{N}=$ jumlah responden;

$\mathrm{X}=$ skor mentah peubah $\mathrm{X}$;

$\mathrm{Y}=$ skor mentah peubah $\mathrm{Y}$

\section{Hasil dan Pembahasan}

\section{Gambaran Umum Taman Anggrek Ragunan}

Taman Anggrek Ragunan berdiri pada tahun 1973 berdasarkan Surat Keputusan Gubernur No. 3 tahun 1973, yang berisi tentang pemberian izin kepada koperasi anggrek Jakarta untuk mengelola Taman Anggrek Ragunan. Kawasan Taman Anggrek Ragunan merupakan milik Pemda DKI Jakarta, yang bertujuan sebagai wadah bagi para petani untuk melakukan usaha-usaha agribisnis anggrek. Pengelolaan Taman Anggrek Ragunan dilakukan oleh Pemerintah DKI Jakarta Cq. Dinas Pertanian dan Kehutanan berdasarkan Surat Gubernur KDKI Jakarta Nomor : 223/-1.853.2 tanggal 20 Juli 1993, dan Surat Keputusan Gubernur Kepala Daerah 
Tabel 1 Karakteristik responden

\begin{tabular}{|c|c|c|c|}
\hline No. & $\begin{array}{c}\text { Karakteristik } \\
\text { Responden }\end{array}$ & Kategori Karakteristik Responden & Jumlah Responden \\
\hline \multirow[t]{3}{*}{1.} & \multirow[t]{3}{*}{ Umur } & 1. Muda $(<18$ tahun) & 0 \\
\hline & & 2. Dewasa (18 -50 tahun $)$ & 29 \\
\hline & & 3. Tua ( $>50$ tahun) & 6 \\
\hline \multirow[t]{3}{*}{2.} & \multirow[t]{3}{*}{ Tingkat Pendidikan } & 1. SD (rendah) & 1 \\
\hline & & 2. SMP (sedang) & 1 \\
\hline & & 3. > SMA (tinggi) & 33 \\
\hline \multirow[t]{3}{*}{3.} & \multirow[t]{3}{*}{ Kepemilikan TI } & 1. HP (rendah) & 18 \\
\hline & & 2. HP dan komputer (sedang) & 13 \\
\hline & & 3. HP, telepon rumah dan komputer (tinggi) & 4 \\
\hline \multirow[t]{3}{*}{4.} & \multirow[t]{3}{*}{ Lama menggunakan TI } & 1. $<5$ bulan (rendah) & 0 \\
\hline & & 2. $5-12$ bulan (sedang) & 4 \\
\hline & & 3. $>12$ bulan (tinggi) & 31 \\
\hline \multirow{3}{*}{5.} & \multirow{3}{*}{$\begin{array}{l}\text { Jenis pelatihan yang } \\
\text { pernah diikuti }\end{array}$} & 1. $1-3$ kali (rendah) & 10 \\
\hline & & 2. $3-7$ kali (sedang) & 17 \\
\hline & & 3. $>7$ kali (tinggi) & 8 \\
\hline \multirow{10}{*}{6.} & \multirow[t]{10}{*}{ Persepsi terhadap TI } & a.kesesuaian telepon genggam dengan kebutuhan & \\
\hline & & 1. $<33 \%$ (kurang sesuai) & 5 \\
\hline & & 2. $33-66 \%$ (sesuai) & 25 \\
\hline & & 3. $>66 \%$ (sangat sesuai) & 5 \\
\hline & & $\begin{array}{l}\text { b.kemudahan telepon genggam untuk } \\
\text { diaplikasikan }\end{array}$ & \\
\hline & & 1. Menerapkan kurang dari 5 kali (sulit) & 7 \\
\hline & & 2. Menerapkan 5 - 10 kali (mudah) & 22 \\
\hline & & $\begin{array}{l}\text { 3. Menerapkan lebih dari } 10 \text { kali (sangat } \\
\text { mudah) }\end{array}$ & 6 \\
\hline & & $\begin{array}{l}\text { c. Kebijakan (peraturan) terhadap penggunaan } \\
\text { telepon genggam }\end{array}$ & \\
\hline & & 1. Tidak mengetahui & 22 \\
\hline \multirow{5}{*}{7.} & \multirow{5}{*}{$\begin{array}{l}\text { Motivasi menggunakan } \\
\text { TI }\end{array}$} & 2. Mengetahui & 11 \\
\hline & & 3. Sangat mengetahui & 2 \\
\hline & & 1. Diri sendiri (rendah) & 7 \\
\hline & & 2. Diri sendiri dan keluarga (sedang) & 19 \\
\hline & & 3. Diri sendiri, keluarga dan lingkungan (tinggi) & 9 \\
\hline
\end{tabular}

Khusus Ibukota Jakarta Nomor 1435 tanggal 19 Oktober 1994. Karakter dominan dari lingkungan wisata Ragunan adalah taman margasatwa, taman anggrek, graha pemuda, balai benih induk, dan bumi perkemahan.

\section{Karakteristik Responden}

Karakteristik responden merupakan peubah yang berhubungan dengan perilaku responden dalam memanfaatkan media cyber extension dan 
berhubungan dengan manfaat sebelum dan setelah pemanfaatan cyber extension. Pemanfaatan cyber extension merupakan salah satu media penyuluhan yang dapat digunakan untuk membantu responden mengembangkan usaha tani tanaman anggrek.

Responden penelitian digolongkan menjadi tiga kelompok usia, yaitu muda : $(<18$ tahun), dewasa (18-50 tahun ) dan tua ( $>50$ tahun). Sebagian besar responden (29 orang) berada pada kategori usia dewasa, responden dengan usia dewasa tampak lebih aktif dalam memanfaatkan teknologi untuk pertanian (tanaman hias) seperti Hp untuk pengembangan usaha tanaman hias dan memperluas jaringan pemasaran. Responden yang berumur dewasa termasuk dalam golongan usia produktif pada kegiatan memiliki semangat dan kreatif untuk mencari berbagai alternatif usaha yang dapat menambah penghasilan dalam rangka memenuhi kebutuhan keluarganya. Warren et al., (2000) menyatakan bahwa penerapan teknologi informasi dan komunikasi sangat terkait dengan tingkat pendidikan, ukuran (skala) usaha pertanian dan efek negatif dari umur petani.

Berdasarkan Tabel 1 tingkat pendidikan responden sebanyak 33 orang sudah memiliki pendidikan kategori tinggi ( $>$ SMA). Responden yang memanfaatkan teknologi informasi seperti Hp, cenderung memiliki pendidikan yang relatif tinggi karena memahami pentingnya penggunaan media teknologi tersebut. Pendidikan yang memadai juga akan membantu responden dalam meningkatkan pengetahuan dan keterampilannya yang dapat menentukan berhasil atau tidaknya kegiatan usaha tani.

Kepemilikan TI responden masih berada pada kategori rendah karena mayoritas menggunakan Hp saja sebanyak 18 orang. Kepemilikan TI berada di kategori tinggi ketika responden memiliki hp, komputer dan telepon rumah. Berdasarkan kategori lama menggunakan TI, sebanyak 31 orang responden telah lama menggunakan TI. Hal ini membuktikan bahwa teknologi sangat cepat masuk dan beredar di lingkungan responden, namun responden memilih untuk menggunakan teknologi hp yang lebih gampang dan lebih sering di update sehingga lebih mudah digunakan.

Kepemilikan TI berada pada kategori rendah karena hanya memiliki telepon genggam saja. Meskipun berada pada kategori rendah, pemanfaatan telepon genggam dimanfaatkan secara optimal sesuai kebutuhan. Pemanfaatan dan aplikasi cyber extension yang maksimal digunakan responden adalah melalui telepon genggam. Telepon genggam digunakan oleh responden dalam berkomunikasi

Tabel 2 Jumlah responden berdasarkan kategori peubah lingkungan untuk pemanfaatan cyber extension

\begin{tabular}{|c|c|c|c|c|c|c|c|}
\hline \multirow[b]{2}{*}{ No } & \multirow{2}{*}{$\begin{array}{c}\text { Kategori } \\
\text { Lingkungan }\end{array}$} & \multicolumn{2}{|c|}{ Kurang } & \multicolumn{2}{|c|}{ Cukup } & \multicolumn{2}{|c|}{ Sangat Cukup } \\
\hline & & Jumlah & $\begin{array}{c}\text { Persentase } \\
(\%)\end{array}$ & Jumlah & $\begin{array}{c}\text { Persentase } \\
(\%)\end{array}$ & Jumlah & $\begin{array}{c}\text { Persentase } \\
(\%)\end{array}$ \\
\hline 1 & \multicolumn{7}{|c|}{ Ketersediaan media komunikasi konvensional } \\
\hline \multicolumn{2}{|c|}{$\begin{array}{l}\text { a. Keberadaan pertemuan } \\
\text { dengan penyuluh }\end{array}$} & 10 & 28,6 & 23 & 65,7 & 2 & 5,7 \\
\hline \multicolumn{2}{|c|}{$\begin{array}{l}\text { b. Keberadaan pertemuan } \\
\text { dengan kelompok tani }\end{array}$} & 11 & 31,4 & 18 & 51,4 & 6 & 17,1 \\
\hline \multicolumn{2}{|c|}{$\begin{array}{l}\text { c. Keberadaan media cetak } \\
\text { yang dapat dimanfaatkan }\end{array}$} & 5 & 14,3 & 26 & 74,3 & 4 & 11,4 \\
\hline \multirow[b]{2}{*}{ No } & \multirow{2}{*}{$\begin{array}{c}\text { Kategori } \\
\text { Lingkungan }\end{array}$} & \multicolumn{2}{|c|}{ Kurang Memadai } & \multicolumn{2}{|c|}{ Memadai } & \multicolumn{2}{|c|}{ Sangat Memadai } \\
\hline & & Jumlah & $\begin{array}{c}\text { Persentase } \\
(\%)\end{array}$ & Jumlah & $\begin{array}{c}\text { Persentase } \\
(\%)\end{array}$ & Jumlah & $\begin{array}{l}\text { Persentase } \\
\quad(\%)\end{array}$ \\
\hline \multicolumn{8}{|c|}{ Ketersediaan sarana akses informasi berbasis teknologi informasi } \\
\hline \multicolumn{2}{|c|}{ a. Telepon rumah } & 23 & 65,7 & 8 & 22,8 & 4 & 11,4 \\
\hline \multicolumn{2}{|c|}{ b. Telepon genggam } & 0 & 0 & 28 & 80 & 7 & 20 \\
\hline \multicolumn{2}{|c|}{ c. Komputer } & 16 & 45,7 & 15 & 42,8 & 4 & 11,4 \\
\hline \multicolumn{2}{|c|}{ d. Komputer berinternet } & 16 & 45,7 & 15 & 42,8 & 4 & 11,4 \\
\hline \multicolumn{2}{|c|}{ e. Warnet } & 25 & 71,4 & 9 & 25,7 & 1 & 2,9 \\
\hline
\end{tabular}


di keseharian, terutama untuk mengecek kondisi kavling. Selain itu, telepon genggam dimanfaatkan untuk menerima orderan baik dari dalam maupun dari luar kota. Dengan memanfaatkan teknologi telepon genggam yang sudah berinternet, efektivitas yang dirasakan responden adalah dapat mengakses informasi berbasis teknologi untuk membantu pengembangan usaha tani lebih cepat dan lebih simpel hanya dengan genggaman tangan. Efisiensi dari segi waktu dan biaya juga dirasakan oleh responden ketika menggunakan telepon genggam, dibandingkan menggunakan komputer dan telepon rumah.

Penelitian Mulyandari (2011) menyatakan bahwa sarana teknologi informasi yang terbanyak dimiliki oleh responden adalah telepon genggam yaitu sebanyak $85 \%$ petani responden telah memilikinya. Berdasarkan hasil pengamatan dan wawancara dengan responden, diketahui bahwa sebenarnya jenis atau tipe telepon genggam yang dimiliki petani sebagian besar sudah merupakan media konvergen yang dapat digunakan untuk mendengarkan radio, mengakses internet, sebagai kamera maupun video, bahkan ada beberapa di antaranya yang sudah dapat digunakan untuk menonton siaran televisi.

Jenis pelatihan yang pernah diikuti oleh responden berada pada kategori sedang yaitu sebanyak 3-7 kali pernah mengikuti pelatihan. Berdasarkan pengalaman para responden dalam mengikuti pelatihan, hampir sebagian besar pelatihan yang diikuti mengenai tanaman hias. Sedangkan pelatihan mengenai akses informasi tentang anggrek dan pemasarannya melalui cyber extension masih banyak responden yang belum mengetahui.

Berdasarkan hasil penelitian menunjukkan bahwa persepsi petani terhadap tiga karakteristik cyber extension pada umumnya sudah cukup baik dengan uraian untuk masing-masing karakteristik cyber extension sebagai berikut : (1) Sebanyak 25 responden menyatakan bahwa pemanfaatan teknologi informasi dalam komunikasi inovasi pertanian (cyber extension) sudah sesuai dengan kebutuhan. Teknologi informasi yang digunakan, terutama telepon genggam telah menjadi sarana pokok dalam berkomunikasi untuk mendukung kegiatan usaha tani responden khususnya untuk mengelola usaha tani dan proses pemasaran. (2) Pada umumnya 22 responden mengatakan bahwa mereka dapat dengan mudah mengaplikasikan sarana teknologi informasi yang digunakan khususnya ialah telepon genggam. Telepon genggam digunakan untuk berkomunikasi baik menelepon, mengirimkan pesan bahkan mengirim email. Persepsi responden dalam mengaplikasikan telepon genggam berada pada kategori mudah. Telepon genggam sudah dimiliki oleh responden sejak lama dan berkembang kegunaannya sehingga dimodifikasi sesuai dengan kebutuhan dari pengguna telepon genggam. Hal inilah yang membuat responden lebih menggunakan telepon genggam dalam mencari informasi dan memasarkan produk usaha tani. Kemudahan aplikasi

Tabel 3 Nilai hubungan antara karakteristik responden dengan perilaku dalam memanfaatkan cyber extension

\begin{tabular}{lccc}
\hline \multicolumn{1}{c}{ Peubah } & Akses CE & $\begin{array}{c}\text { Intensitas } \\
\text { pemanfaatan } \\
\text { telepon genggam }\end{array}$ & $\begin{array}{c}\text { Intensitas } \\
\text { pemanfaatan } \\
\text { komputer }\end{array}$ \\
\hline Umur & $0,479(* *)$ & 0,152 & $-0,284$ \\
Tingkat pendidikan & 0,165 & 0,126 & $-0,286$ \\
Kepemilikan TI & $-0,443 \quad(* *)$ & $-0,066$ & 0,075 \\
Lama menggunakan TI & $-0,308$ & $-0,226$ & 0,134 \\
Jenis pelatihan yang pernah diikuti & $-0,409 \quad\left(^{*}\right)$ & $-0,067$ & $0,396 \quad(*)$ \\
Persepsi petani (kesesuaian dengan & 0,000 & 0,111 & $-0,077$ \\
kebutuhan) & 0,162 & 0,036 & 0,167 \\
$\begin{array}{l}\text { Persepsi petani (kemudahan untuk } \\
\text { diaplikasikan) }\end{array}$ & 0,056 & $-0,042$ & $-0,059$ \\
Persepsi petani (kebijakan terhadap CE) & $-0,082$ & $-0,023$ & $0,435 \quad(* *)$ \\
Motivasi petani & & & \\
\hline
\end{tabular}


telepon genggam juga meningkatkan keuntungan karena mampu menerima konsumen dari luar daerah. Berdasarkan hasil penelitian Mulyandari (2011) juga diketahui bahwa hampir seluruh (93\%) persen responden menyatakan bahwa aplikasi teknologi informasi dalam implementasi cyber extension mudah dan sangat mudah dilihat hasilnya. Hal ini berbanding lurus dengan keuntungan relatif yang dapat dirasakan dengan adanya cyber extension. Petani yang belum mampu mengakses cyber extension pun sudah dapat melihat bahwa dengan adanya cyber extension, informasi yang dibutuhkan dapat lebih cepat diakses dan dapat memperluas jaringan pemasaran. (3) Berdasarkan hasil penelitian juga diketahui bahwa sebanyak 22 orang menyatakan bahwa kebijakan terhadap telepon genggam tidak diketahui. Hal ini dikarenakan kurangnya sosialisasi cyber extension di tingkat responden. Selain itu, kebijakan terkait tanaman hias, baik perlindungan, pembudidayaan, pemasaran dan yang lainnya masih sangat minim di kalangan responden. Banyak responden yang tidak mengetahui adanya kebijakan tersebut.

Motivasi dalam menggunakan TI sebanyak 19 orang (sedang) berasal dari diri sendiri dan keluarga. Keluarga merupakan salah satu faktor yang memotivasi petani dalam memanfaatkan teknologi untuk dapat membantu dalam berusaha tani. Bahkan terdapat responden yang juga dibantu oleh keluarganya dalam melakukan usaha tani. Relasi dan rekanan dari responden juga memotivasi untuk menggunakan TI, karena dalam berkomunikasi dengan relasi, responden lebih banyak menggunakan telepon genggam deibandingkan bertatap muka secara langsung. Berbeda dengan penelitian Amin (2013), menyatakan bahwa motivasi petani untuk menggunakan ekstensi cyber extension dianggap rendah karena masih rendahnya kemampuan petani untuk mengakses ICT, serta masih kurangnya keterampilan dan juga pengetahuan di atasnya. Untuk mengubah kondisi ini harus ada motivasi dari dalam diri sendiri untuk dapat meningkatkan keterampilan dan pengetahuan para petani tentang teknologi.

\section{Lingkungan}

Lingkungan terdiri dari ketersediaan media komunikasi konvensional dan ketersediaan sarana akses informasi berbasis teknologi informasi. Lingkungan merupakan salah satu faktor yang mempengaruhi responden dalam memanfaatkan cyber extension. Dengan tersedianya media komunikasi baik konvensional maupun media berbasis teknologi, responden dapat mengakses berbagai informasi yang dibutuhkan. Ketersediaan media komunikasi yang di teliti adalah media komunikasi konvensional dan media informasi berbasis teknologi informasi.

Ketersediaanmediakomunikasikonvensional terdiri dari keberadaan kegiatan pertemuan dengan penyuluh, keberadaan kegiatan pertemuan dengan kelompok tani dan keberadaan media cetak yang dapat dimanfaatkan. Keberadaan pertemuan dengan penyuluh 23 responden menyatakan cukup (Tabel 2).

Sumaryanto dan Siregar (2003) menyatakan

Tabel 4 Nilai hubungan antara lingkungan dengan perilaku dalam memanfaatkan cyber extension

\begin{tabular}{lccc}
\hline \multicolumn{1}{c}{ Peubah } & Akses CE & $\begin{array}{c}\text { Intensitas } \\
\text { pemanfaatan } \\
\text { telepon genggam }\end{array}$ & $\begin{array}{c}\text { Intensitas } \\
\text { pemanfaatan } \\
\text { komputer }\end{array}$ \\
\hline Keberadaan pertemuan dengan penyuluh & 0,060 & 0,003 & $-0,257$ \\
Keberadaan pertemuan dengan kelompok tani & 0,169 & $-0,074$ & $-0,104$ \\
Keberadaan media cetak & 0,008 & $-0,043$ & 0,201 \\
Ketersediaan telepon rumah & $-0,043$ & $-0,005$ & $-0,079$ \\
Ketersediaan telepon genggam & 0,308 & 0,059 & $-0,186$ \\
Ketersediaan komputer & $-0,279$ & $-0,391 \quad(*)$ & $0,460 \quad(* *)$ \\
Ketersediaan komputer berinternet & 0,070 & 0,046 & 0,185 \\
Ketersediaan warnet & $-0,267$ & $-0,443 \quad(* *)$ & $0,632 \quad(* *)$ \\
\hline
\end{tabular}

** Korelasi signifikan pada tingkat 0,01

* Korelasi signifikan pada tingkat 0,05 
bahwa faktor lingkungan tidak dapat dikendalikan oleh seseorang. Lebih jauh dikemukakan bahwa ada dua faktor eksternal yaitu faktor eksternal yang berada di luar kendali seseorang (strictly externax dan faktor eksternal yang seseorang dapat mengendalikannya dengan bantuan orang lain (quasi externa). Keberadaan pertemuan dengan kelompok tani 18 responden menyatakan cukup. Hal ini dikarenakan pertemuan dengan kelompok tani rutin dilaksanakan. Keberadaan kelompok tani, membantu dalam usaha tani tanaman hias yang dijalankan oleh anggota kelompok tani. Kelompok tani membantu dalam hal informasi, pembibitan, pupuk dan bantuan modal. Dengan adanya bantuan tersebut, anggota kelompok tani menjadi termotivasi dalam menjalankan usahanya. Selain itu, kelompok tani juga sering mengadakan dan mengikuti perlombaan dan pameran tanaman hias yang bekerja sama dengan pemerintah, swasta, kelompok hobbi dan yang lainnya.

Keberadaan berbagai media cetak yang dapat dimanfaatkan oleh responden berada pada kategori cukup. Keberadaan media cetak merupakan media konvensional yang paling banyak digunakan oleh responden dibandingkan dengan media konvensional lainnya seperti pertemuan dengan penyuluh dan pertemuan dengan kelompok tani. Keberadaan media cetak lebih tinggi nilainya karena intensitas keberadaan media cetak yang hampir tiap hari terbit. Dari media cetak tersebut, responden dapat memperoleh informasi perkembangan terkait usaha tani dan berita-berita lainnya.

Ketersediaan media berbasis teknologi informasi yang terdiri dari telepon rumah, telepon genggam, komputer berinternet dan warnet memiliki nilai yang berbeda-beda. Ketersediaan telepon rumah sangat kurang karena responden lebih nyaman menggunakan telepon genggam.

Ketersediaan sarana komputer juga memiliki nilai yang masih kurang memadai bagi 16 orang responden, hal ini dikarenakan sedikitnya responden yang memiliki dan memanfaatkan komputer untuk mendapatkan informasi. Responden lebih banyak memanfaatkan telepon genggam untuk memperoleh informasi karena keberadaan telepon genggam selalu di bawa ke mana responden berada. Berbeda dengan komputer yang biasanya selalu di tempat yang sama seperti berada di ruangan kantor.

Terkait dengan fasilitas untuk akses sistem informasi berbasis teknologi informasi berupa warnet, sebanyak 25 responden menyatakan masih sangat tidak memadai. Hal ini dikarenakan jauhnya warnet di sekitar taman anggrek Ragunan. Di sisi lain, untuk mengakses internet, responden lebih memilih menggunakan telepon genggam yang lebih mudah digunakan dan tidak terlalu membuang waktu untuk ke warnet terlebih dahulu. Cyber extension adalah media komunikasi yang baru dengan menggunakan teknologi informasi untuk memperoleh informasi atau pembelajaran. Oleh karena itu, pemerintah melakukan sosialisasi dan memberikan bantuan satu set komputer beserta internet untuk dapat dimanfaatkan oleh penyuluh, petani dan pelaku lainnya. Di Taman Anggrek Ragunan, media komunikasi untuk mengakses cyber extensiontersebut sudah ada, namun belum digunakan karena belum tersedianya jaringan internet. Hal ini juga dikarenakan gedung kantor yang baru selesai di renovasi dan terjadinya pergantian kepengurusan di Taman Anggrek Ragunan.

\section{Hubungan antara Karakteristik Responden dengan Perilaku dalam Pemanfaatan Cyber Extension}

Tujuan perilaku di tentukan oleh sikap atas perilaku tersebut (Sarana, 2000). Dengan demikian dapat dipahami reaksi dan persepsi pengguna teknologi informasi akan mempengaruhi sikapnya dalam penerimaan penggunaan teknologi informasi, yaitu salah satu faktor yang dapat mempengaruhi adalah persepsi pengguna atas kemanfaatan dan kemudahan penggunaan teknologi informasi sebagai suatu tindakan yang beralasan dalam konteks pengguna teknologi informasi, sehingga alasan seseorang dalam melihat manfaat dan kemudahan penggunaan teknologi informasimenjadikan tindakan orang tersebut dapat menerima penggunaan teknologi informasi. Departemen Pendidikan Nasional (2003) mengartikan perilaku sebagai tanggapan atau reaksi individu terhadap rangsangan atau lingkungan. Tiap individu dianggap memiliki pembawaan sendiri yang sulit diubah dan akan berkembang secara kodrat.

Adanya hubungan yang negatif antara umur dengan perilaku dalam pemanfaatan teknologi komputer dapat dipahami karena dalam menggunakan komputer dibutuhkan kemampuan untuk memahami dan tahu bagaimana cara mengoperasikan komputer dengan lancar, sementara responden yang mayoritas 
berusia tua cenderung memiliki tingkat pendidikan yang rendah. Hal ini ditunjukkan dengan adanya hubungan negatif antara umur dengan tingkat pendidikan, persepsi terhadap kesesuaian terhadap kebutuhan, dan persepsi terhadap kebijakan, sebagaimana disajikan dalam Tabel 3. Hal ini sejalan dengan penelitian Amin (2013) bahwa usia para petani berada pada kategori usia produktif tetapi latar belakang pendidikan formal mereka adalah lulusan SMP, sehingga pendidikan yang relatif rendah dari petani. Secara umum, orang-orang yang dapat menggunakan akses untuk ICT adalah lulusan SMA atau mereka yang berhasil untuk melanjutkan ke pendidikan tinggi. Berdasarkan tabel di atas, hubungan antara karakteristik individu dengan perilaku responden dalam pemanfaatan cyber extension, yang memiliki nilai negatif menyatakan bahwa jika salah satu indikator naik, maka indikator lainnya turun, seperti pada usia dimana ketika usia semakin tua, maka pemanfaatan komputer semakin menurun. Hal ini juga terjadi kepada indikator yang memiliki tanda negatif. Sebaliknya untuk tanda positif, apabila indikator yang satu naik, maka indikator lainnya juga ikut naik. Indikator persepsi kesesuaian dengan kebutuhan terhadap indikator pemanfaatan telepon genggam yang bernilai positif, artinya ketika kebutuhan semakin meningkat, maka penggunaan telepon genggam juga meningkat (Tabel 3).

Secara umum, seluruh peubah karakteristik responden yaitu umur, tingkat pendidikan, kepemilikan teknologi informasi, lama menggunakan sarana teknologi informasi, jenis pelatihan yang pernah diikuti, persepsi terhadap TI dan motivasi memiliki hubungan yang nyata dengan perilaku dalam pemanfaatan teknologi informasi khususnya pada aspek akses cyber extension seperti pada Tabel 3. Perkembangan teknologi informasi dan komunikasi dapat digunakan untuk menjembatani informasi dan pengetahuan yang tersebar di antara yang menguasai informasi dan yang tidak. Akses terhadap komunikasi digital membantu meningkatkan akses terhadap peluang pendidikan, meningkatkan transparansi dan efisiensi layanan pemerintah, memperbesar partisipasi secara langsung dari "used to-be-silent-public" (masyarakat yang tidak mampu berpendapat) dalam proses demokrasi, meningkatkan peluang perdagangan dan pemasaran, memperbesar pemberdayaan masyarakat menciptakan jaringan komunikasi dan peluang pendapatan, serta akses terhadap informasi pengobatan untuk masyarakat yang terisolasi dan meningkatkan peluang tenaga kerja (Servaes, 2007).

\section{Hubungan antara Lingkungan dengan Perilaku dalam Pemanfaatan Cyber Extension}

Hasil penelitian yang disajikan pada Tabel 4 merupakan hasil dari nilai hubungan antara lingkungan dengan perilaku dalam pemanfaatan cyber extension. Cyber extension merupakan media komunikasi baru yang mensinergikan aplikasi teknologi untuk komunikasi inovasi dan sarana berbagi informasi. Oleh karena itu, pengembangan media belajar secara terprogram melalui pelatihan dan sosialisasi sangat diperlukan sehingga petani dapat memanfaatkan teknologi informasi yang tersedia dengan optimal (Mulyandari, 2011).

Hubungan yang negatif antara keberadaan pertemuan dengan penyuluh terhadap perilaku dalam pemanfaatan teknologi komputer dapat dipahami karena pertemuan dengan penyuluh merupakan salah satu bentuk komunikasi tatap muka yang langsung terjadi. Berbeda ketika menggunakan komputer, maka komunikasi yang terjadi tetap bisa dua arah, namun menggunakan komputer sebagai media. Responden menyatakan bahwa lebih mudah berkomunikasi langsung dengan penyuluh dibanding menggunakan komputer terlebih dahulu, sehingga tanda negatif pada nilai korelasi tersebut menyatakan hubungan yang tidak searah. Pelatihan dalam menggunakan komputer juga masih sangat minim diberikan kepada responden.

Pada Tabel 4 terdapat indikator yang bernilai positif, seperti pada indikator ketersediaan telepon genggam dengan akses cyber extension, dan pemanfaatan telepon genggam. Hal ini berarti bahwa ketika ketersediaan telepon genggam meningkat, maka akses cyber extensiondan penggunaan telepon genggam juga meningkat, begitu pun indikator lain yang memiliki nilai positif.Sebagaimana dinyatakan oleh Browning et al., (2008) bahwa pemanfaatan teknologi informasi merupakan media baru dalam komunikasi inovasi pertanian. Internet merupakan salah satu bentuk revolusi terkait dengan bagaimana kita dapat bekerja untuk mengelola informasi dan berkomunikasi dengan orang lain secara lebih cepat dan tanpa terkendala ruang dan juga jarak. Dengan menggunakan surat elektronik atau email dan Short Message Service (SMS) kita dapat berkomunikasi 
langsung secara cepat dan berbagi informasi maupun dokumen.

\section{Hubungan antara Karakteristik Responden dengan Manfaat terhadap Usaha Tani sebelum Menggunakan Cyber Extension melalui Telepon genggam}

Secara keseluruhan dari peubah karakteristik individu responden berhubungan secara nyata dengan manfaat usaha tani sebelum menggunakan cyber extension. Terdapat beberapa indikator yang memiliki hubungan korelasi positif dan korelasi negatif, bahkan terdapat indikator yang tidak memiliki hubungan korelasi. Umur memiliki hubungan korelasi negatif terhadap peningkatan produk dan terhadap profit keuntungan. Artinya, ketika umur bertambah tua, peningkatan produk dan profit keuntungan menurun. Umur responden yang bertambah biasanya lebih cenderung untuk melakukan usaha tani sebagai hobbi, bukan untuk mencari keuntungan.

Pada indikator kepemilikan alat TI terhadap peningkatan produk juga memiliki korelasi positif. Hal ini dikarenakan kepemilikan terhadap TI meningkat, peningkatan produk menjadi meningkat karena peningkatan produk dapat dilakukan melalui komunikasi dengan telepon genggam terutama bagi pelanggan dari luar kota. Selain menjual tanaman, responden juga melakukan jasa perentalan tanaman hias bagi kantor perusahaan maupun keperluan sebuah acara. Jasa perentalan tanaman hias yang dilakukan oleh responden biasanya juga dilakukan melalui telepon genggam.

Kepemilikan TI terhadap pengetahuan telepon genggam memiliki korelasi positif. Artinya, semakin tinggi kepemilikan TI responden, maka semakin tinggi juga pengetahuan responden terhadap telepon genggam. Hal ini terlihat karena responden memahami peran dan fungsi telepon genggam sehingga menjadikan telepon genggam sebagai salah satu kebutuhan utama.

Indikator jenis pelatihan yang pernah diikuti memiliki korelasi positif dengan peningkatan konsumen. Hal ini mencerminkan bahwa dengan seringnya responden mengikuti pelatihan, bertambah kemampuan dan pengetahuan sehingga memiliki kemampuan yang lebih untuk memasarkan tanaman hiasnya sehingga terjadi peningkatan konsumen.

Persepsi responden berdasarkan kebutuhan tidak memiliki korelasi terhadap kecenderungan sikap pemanfaatan komputer, komputer berinternet, peningkatan konsumen dan peningkatan profit keuntungan. Persepsi responden berdasarkan kebutuhan dengan kecenderungan sikap terhadap pemanfaatan telepon genggam memiliki hubungan korelasi negatif.

Persepsi responden berdasarkan kebijakan terhadap pengetahuan responden terhadap komputer berinternet berkorelasi negatif. Persepsi responden berdasarkan kebijakan terhadap kecenderungan sikap terhadap pemanfaatan telepon rumah berkorelasi positif. Sehingga ketika kebijakan semakin meningkat, maka penggunaan telepon rumah meningkat. Persepsi terhadap kebijakan dengan kecenderungan sikap pemanfaatan telepon genggam tidak memiliki korelasi (0). Artinya antara kebijakan dengan sikap untuk memanfaatkan telepon genggam tidak memiliki hubungan, sehingga kebijakan yang ada belum berkorelasi dengan baik terhadap penggunaan telepon genggam. Hal ini juga didasari karena masih sangat minimnya sosialisasi kebijakan.

\section{Hubungan antara Lingkungan dengan Manfaat terhadap Usaha Tani sebelum Menggunakan Cyber Extension melalui Telepon genggam}

Indikator keberadaan pertemuan dengan kelompok tani memiliki hubungan korelasi positif dengan kecenderungan sikap terhadap pemanfaatan telepon rumah. Keberadaan kelompok tani dapat membantu responden dalam melaksanakan kegiatan usaha tani. Biasanya untuk menghubungi kelompok tani dan berkomunikasi dengan kantor Gapoktan, Gapoktan memiliki telepon rumah sehingga responden lebih mudah berkomunikasi dengan kelompok tani tanpa harus datang ke kantor Gapoktan.

Keberadaanmediacetakterhadapkecenderungan sikap terhadap pemanfaatan telepon rumah memiliki korelasi negatif. Media cetak merupakan media yang dimiliki oleh responden, dengan cara berlangganan baik harian, mingguan maupun bulanan. Dengan adanya media cetak, biasanya responden tidak menggunakan telepon rumah untuk memperoleh informasi karena media cetak di rasa sudah cukup.

Ketersediaan telepon genggam berhubungan negatif dengan kecenderungan sikap terhadap pemanfaatan telepon rumah. Semakin banyak penggunaan telepon genggam maka penggunaan telepon rumah semakin menurun. Hal ini dikarenakan 
telepon genggam yang lebih mudah di bawa ke mana saja responden berada. Selain itu model dan fungsi telepon genggam sudah semakin canggih dan lebih modern sehingga dapat dijadikan beberapa fungsi.

Ketersediaan telepon genggam memiliki korelasi positif dengan peningkatan konsumen, peningkatan produk serta peningkatan profit keuntungan. Dengan meningkatnya telepon genggam, responden memanfaatkan fungsi telepon genggam secara maksimal. Telepon genggam digunakan untuk memasarkan tanaman hias dan memperoleh informasi perkembangan tanaman yang sedang diminati pasar. Sehingga dengan meningkatnya penggunaan telepon genggam, meningkat juga konsumen, produk dan keuntungan.

Ketersediaan komputer dan juga komputer berinternet berkorelasi positif terhadap peningkatan produk. Komputer merupakan salah satu alat berbasis teknologi yang digunakan oleh responden untuk menyimpan data penjualan dan permintaan konsumen. Dengan adanya komputer, responden dapat menganalisis tanaman yang di minati oleh konsumen, sehingga responden dapat meningkatkan produk agar tetap diminati oleh konsumen.

\section{Hubungan antara Karakteristik Responden dengan Manfaat terhadap Usaha Tani Setelah Menggunakan Cyber Extension melalui Telepon genggam}

Umur berkorelasi negatif dengan pengetahuan petani terhadap penggunaan telepon genggamberinternet dan peningkatan produk. Semakin tua umur responden, pengetahuan telepon genggam semakin menurun karena responden yang semakin tua tidak terlalu tertarik untuk fungsi telepon yang bermacam-macam. Mereka lebih menginginkan telepon genggam yang lebih simpel, bisa menelepon dan sms sudah sangat cukup dirasakan fungsinya bagi responden yang semakin tua. Sedangkan untuk peningkatan produk, semakin tua umur responden, biasanya mereka memberikan ide kepada yang lebih muda dan dewasa untuk melakukan pengembangan produk.

Persepsi terhadap kemudahan diaplikasikan memiliki korelasi positif dengan kecenderungan sikap memanfaatkan telepon genggam. Di lapangan terlihat bahwa dengan adanya kemudahan aplikasi penggunaan telepon genggam, semakin tinggi minat responden untuk menggunakan telepon genggam.
Persepsi terhadap kebijakan berkorelasi negatif terhadap pengetahuan komputer berinternet. Meskipun responden menggunakan komputer, responden tidak memahami kebijakan yang mengatur dari penggunaan komputer. Persepsi responden terhadap kebutuhan berkorelasi positif dengan peningkatan konsumen. Kebutuhan yang dirasakan oleh responden memiliki hubungan terhadap peningkatan konsumen karena dengan meningkatnya kebutuhan, responden harus berpikir agar keuntungan dapat meningkat melalui konsumen.

Persepsi dari para responden terhadap kebutuhan memiliki hubungan negatif dengan kecenderungan sikap memanfaatkankomputerberinternet. Kebutuhan responden dalam meningkatkan produk, cenderung berdiskusi dengan grup sesama tanaman hias yang biasanya dilakukan dengan menggunakan telepon genggam. Penggunaan komputer sangat sedikit digunakan untuk memenuhi kebutuhan karena lebih nyaman menggunakan telepon genggam. Jenis pelatihan berkorelasi positif dengan peningkatan produk serta profit keuntungan. Responden yang sering mengikuti pelatihan dan pameran tanaman hias memiliki keunggulan dalam mengetahui informasi terutama dalam pengembangan produk, sehingga dapat diaplikasikan ketika berada di kavling dan meningkatkan nilai keuntungan.

Motivasi responden berkorelasipositifterhadap kecenderungan sikap dalam memanfaatkan telepon genggam dan profit keuntungan. Motivasi merupakan dorongan yang dimiliki oleh responden untuk melakukan komunikasi dan memenuhi kebutuhan. Motivasi responden untuk dapat berkomunikasi dengan responden lainnya maupun dengan konsumen menjadikan pemanfaatan telepon genggam salah satu alat yang dapat digunakan. Dengan adanya motivasi yang tinggi, rasa ingin mencukupi kebutuhan semakin meningkat sehingga memiliki inovasi untuk mendapatkan keuntungan.

\section{Hubungan antara Lingkungan dengan Manfaat terhadap Usaha Tani setelah Menggunakan Cyber Extension melalui Telepon genggam}

Ketersediaan telepon genggam berkorelasi positif terhadap profit keuntungan dan peningkatan konsumen. Penggunaan telepon genggam menjadi kebutuhan utama dalam berkomunikasi dengan konsumen dan juga produsen dari tanaman hias. Penggunaan telepon genggam lebih efektif digunakan oleh responden untuk menerima pesanan, terutama 
untuk pemesanan dari luar Jakarta. Dengan kondisi taman anggrek Ragunan yang saat ini lebih sepi dari konsumen, penggunaan telepon genggam sangat membantu dalam peningkatan keuntungan. Hal ini juga dikarenakan pelanggan dari tiap kavling yang lebih sering menggunakan telepon genggam untuk membeli dibandingkan untuk datang langsung ke taman anggrek Ragunan.

Ketersediaan komputer dan jaringan komputer berinternet berkorelasi positif dengan peningkatan produk dan profit keuntungan. Penggunaan komputer bagi responden adalah untuk menyimpan data penjualan dan permintaan karena beberapa responden menyatakan komputer tidak disambungkan dengan jaringan internet. Dengan adanya data tersebut, responden dapat mengkalkulasikan penjualan perbulan bahkan pertahun sehingga dapat melihat bagaimana grafik konsumen serta keuntungan yang diperoleh.

Tingkat ketersediaan warnet memiliki hubungan positif dengan peningkatan produk. Ketersediaan warnet dimanfaatkan oleh responden untuk mencari informasi tentang pengembangan produk dan informasi pameran tanaman hias. Hal ini dikarenakan tidak semua responden memiliki komputer, bahkan komputer berinternet. Sehingga penggunaan warnet menjadi salah satu alternatif dalam memperoleh informasi.

\section{Kesimpulan}

Karakteristik para responden dan lingkungan memiliki hubungan nyata dengan perilaku responden dalam memanfaatkan cyber extension, khususnya telepon genggam. Manfaat dari telepon genggam dalam keseharian responden adalah sebagai sarana komunikasi dengan konsumen dan akses informasi. Efisiensi dari pemanfaatan telepon genggam dirasakan responden dari sisi biaya, waktu dan tenaga kerja.

Karakteristik responden dan lingkungan memiliki hubungan nyata dengan pemanfaatan cyber extension baik sebelum maupun setelah memanfaatkan telepon genggam. Sebelum memanfaatkan telepon genggam, responden kesulitan menghadapi konsumen yang berasal dari luar daerah, setelah memanfaatkan telepon genggam konsumen dapat berkomunikasi dengan responden melalui telepon genggam meskipun berada pada jarak yang sangat jauh.

\section{Daftar Pustaka}

Adekoya AE. 2007. Cyber extension communication: A strategic model for agricultural and rural transformation in Nigeria. International journal of food, agriculture and environment 5(1): 366-368.

Alemna AA, Joel S. 2006. Critical Issues in Information and Communication Technologies for Rural Development in Ghana. Information Development 22(4). SAGE Publications.

Amin. 2013. The effectiveness of cyber extension based information technology to support agricultural activities in Kabupaten Donggala, Central Sulawesi Province, Indonesia. International Journal of Asian Social Science 3(4): 882-889.

Arikunto. 1998. Prosedur Penelitian Suatu Pendekatan Praktek. Jakarta (ID): PT. Rineka Cipta.

Batte MT, Jones E, Schnitkey GD. 1990. Computer use by Ohio commercial farmers. American Journal of Agricultural Economics 72: 935 - 945.

Browning LD, Saetre AS, Stephens KK, Sornes JO. 2008. Information and Communication Technology in Action. Linking Theory and Narratives of Practice. New York and London: Routledge.

Departemen Pendidikan Nasional, Pusat Bahasa. 2003. Kamus Bahasa Indonesia. Jakarta (ID).

Johnson, Witchern. 2002. Applied Multivariate Statistical Analysis. Fifth Edition. New Jersey: Pearson Education.

Mulyandari RSH. 2011. Cyber extension sebagai media komunikasi dalam pemberdayaan petani sayuran [disertasi]. Bogor (ID): Institut Pertanian Bogor.

Sarana. 2000. Pengaruh persepsi kemudahan, perpsepsi kemanfaatan, kecemasan, sikap, dan penggunaan mikrokomputer terhadap hasil kerja akuntan pendidik. [tesis]. Semarang (ID): Program Studi Magister Akuntansi, Universitas Diponegoro.

Servaes J. 2007. Harnessing the UN System Into a Common Approach on Communication for Development. International Communication Gazette 2007; 69; 483.

Sumaryanto, Siregar M. 2003. Determinasi Efisiensi Teknis Usahatani Padi di Lahan Sawah Irigasi. Jurnal Agro Ekonomi 21(1), mei 2003. Bogor (ID): Pusat Penelitian dan Pengembangan Sosial Ekonomi Pertanian. 
Jurnal Penyuluhan, September 2015 Vol. 11 No. 2

Sumardjo, Baga LM, Mulyandari RSH. 2009. Kajian Cyber extension (Laporan Kegiatan). Departemen Pertanian.

Susanto D. 2008. Peran Penyuluhan Pembangunan dalam Peningkatan Kualitas SDM Dalam Pemberdayaan Manusia Pembangunan yang Bermartabat. Disunting oleh: Adjat Sudrajat dan Ida Yustina. Bogor (ID): Sydex Plus
Taragola N, Gelb E. 2009. Information and communication Technology (ICT) adoption in Horticulture: comparison of the EFITA, ISHS, and ILVO questionnaires.

Warren MF, Soffe RJ, Stone MAH. 2000. Farmers, computers and the internet: a study of adoption in contrasting regions of England. Farm Management, $10,11,665-684$. 